\title{
PENGARUH METODE TEBAK KATA TERHADAP KETERAMPILAN MENULIS PUISI SISWA KELAS IV SDN TAMAN CIBODAS KOTA TANGERANG
}

\author{
Dilla Fadhillah \\ Universitas Muhammadiyah Tangerang \\ Jln. Perintis Kemerdekaan I No.1, Babakan, Tangerang, Indonesia \\ Email: dillafadhillah@umt.ac.id
}

\begin{abstract}
Abstrak
Penelitian ini bertujuan untuk mengetahui pengaruh keterampilan menulis siswa pada mata pelajaran Bahasa Indonesia materi menulis puisi antara siswa yang diberikan metode tebak kata dengan metode konvensional. Penelitian ini menggunakan metode eksperimen semu dengan desain Nonequivalent Control Group Design. Populasi dalam penelitian ini adalah seluruh siswa kelas IV SDN Taman Cibodas yang berjumlah 62 siswa. Kelas IVA yang berjumlah 32 siswa diambil sebagai kelas eksperimen dan kelas IVB yang berjumlah 32 siswa diambil sebagai kelas kontrol. Teknik pengumpulan data menggunakan teknik tes dengan instrumen soal tes keterampilan menulis berbentuk esai yang terdiri dari 1 soal yang telah diuji validitas. Pengujian hipotesis dalam penelitian ini digunakan uji-t. Hasil penelitian menunjukkan bahwa terdapat pengaruh yang signifikan metode tebak kata terhadap kemampuan menulis puisi siswa kelas IV SDN Taman Cibodas. Hal ini dibuktikan dengan pengujian hipotesis postes dari hasil uji-t diperoleh $t_{\text {hitung }}=4,47$ dan $t_{\text {tabel }}=2,00$. Dengan demikian, hal ini dapat diartikan bahwa keterampilan menulis dengan menggunakan metode tebak kata lebih tinggi dari pada menggunakan metode pembelajaran konvensional.
\end{abstract}

Kata kunci: Metode Tebak Kata, Keterampilan Menulis Puisi

\section{THE EFFECT OF WORD GUESS METHOD TOWARD STUDENTS' POETRY WRITING SKILLS AT IV GRADE IN SDN TAMAN CIBODAS KOTA TANGGERANG}

\begin{abstract}
The purpose of this study was to determine the effect of students' writing skills in Indonesian language subjects for material writing poetry between students who were given the Word Guess Method and conventional method. This research uses quasi-experimental method with Nonequivalent Control Group Design. The population in this study was all fourth grade students of Taman Cibodas Elementary School, with the total number were 62 students. Class IVA with the number of students were 32 students as the experimental class, and class IVB with the number of students were 32 students as the control class. Data collection techniques using test techniques with essay writing skills test instruments consisting of 1 item that has been tested for validity. Hypothesis testing in this study used the t-test. The
\end{abstract}


results showed that there was a significant influence on the method of guessing words on the ability to write poetry for fourth grade students at SDN Taman Cibodas. This is evidenced by testing the posttest hypothesis from the results of the t-test obtained $t_{\text {count }}=4.47$ and $t_{\text {table }}=2.00$. Thus, this can be interpreted that the writing skills using the word guessing method are higher than using conventional learning methods.

Keywords: Word Guess Method, Poetry Writing Skill

\section{A. Pendahuluan}

Pendidikan adalah hal yang sangat berperan dalam perkembangan keilmuan yang dimiliki oleh setiap manusia. Pendidikan di Indonesia saat ini sangat pesat dimulai dari jenjang pendidikan nonformal sampai dengan pendidikan formal. Di sekolah dasar, para siswa diajarkan berbagai macam ilmu dari mata pelajaran yang berbeda. Salah satunya adalah mata pelajaran Bahasa Indonesia yang sudah menjadi bahasa persatuan menjadi mata pelajaran wajib. Mata pelajaran Bahasa Indonesia tidak hanya diberikan di jenjang pendidikan Sekolah Dasar, tetapi sampai jenjang perguruan tinggi. Empat keterampilan dalam bahasa Indonesia yaitu menyimak, berbicara, membaca, dan menulis harus mampu dikuasai oleh siswa (Tarigan, 2008). Keterampilan menulis menjadi materi penelitian ini, yaitu berkaitan dengan kemampuan menulis puisi siswa kelas IV.

Keterampilan menulis bagi siswa merupakan keterampilan yang paling sulit. Mereka harus mampu menyusun kata-kata ke dalam sebuah puisi. Banyak siswa yang sangat kesulitan menulis sebuah puisi daripada menulis sebuah karangan. Selain menyusun kata-kata, mereka harus mampu memilih diksi yang tepat ketika menuangkannya dalam sebuah puisi. Hal ini tentu sangat berkaitan dengan metode pembelajaran yang digunakan guru dalam mengajar. Berdasarkan hasil observasi yang dilakukan oleh peneliti, metode yang digunakan dalam mengajar masih belum memberikan motivasi yang kuat dalam kegiatan menulis puisi. Dalam kegiatan wawancara, guru mengutarakan kesulitan menemukan metode yang sesuai dengan materi menulis puisi. Siswa pernah dibawa untuk belajar di luar kelas dengan tujuan mempermudah mendapatkan ide-ide untuk menulis puisi, tetapi hasil yag didapat kurang makimal karena siswa sulit untuk dikondisikan ketika berada di luar kelas.

Untuk mengatasi permasalahan tersebut, diperlukan metode pembelajaran yang dapat meningkatkan keterampilan menulis. Salah satu metode pembelajaran 
yang dapat meningkatkan motivasi dan menarik perhatian siswa adalah metode tebak kata. Metode ini melibatkan semua siswa dalam pelaksanaannya sehingga pikiran dan perhatian siswa akan tetap tertuju pada kegiatan pembelajaran yang sedang berlangsung. Metode tebak kata merupakan salah satu penerapan pembelajaran yang memberikan kesempatan kepada siswa, terutama pada siswa pemalu dan pasif pada proses pembelajaran untuk melatih keberanian dalam mengemukakan pendapat.

Simulasi untuk metode tebak kata, siswa dibuat beberapa kelompok, dari setiap kelompok terdapat dua orang perwakilan untuk maju ke depan, kemudian diberikan sebuah amplop yang di dalamnya terdapat kartu bertuliskan beberapa kata. Satu siswa membacakan kata petunjuknya, siswa lain mencoba menebak kata yang terdapat di kartu tersebut. Ketika sudah berhasil ditebak siswa dan kelompoknya menuliskan puisi sesuai dengan tema yang berhasil ditebak oleh temannya.

Terdapat empat keterampilan dalam bahasa Indonesia, menyimak, berbicara, membaca, dan menulisi. Keterampilan menulis akan dijelaskan secara rinci karena termasuk ke dalam variabel terikat penelitian ini. Menurut Fadhillah, dkk. (2019), menulis merupakan sebuah proses kreatif menuangkan gagasan dalam bentuk bahasa tulis dalam tujuan, misalnya memberi tahu, meyakinkan, atau menghibur. Hasil dari proses kreatif ini biasa disebut dengan istilah karangan atau tulisan. Kedua istilah tersebut mengacu pada hasil yang sama meskipun ada pendapat yang mengatakan kedua istilah tersebut memiliki pengertian yang berbeda. Istilah menulis sering melekatkan pada proses kreatif yang sejenis ilmiah sementara istilah mengarang sering dilekatkan pada proses kreatif yang berjenis nonilmiah. Menulis juga dapat dikatakan sebagai kegiatan merangkai huruf menjadi kata atau kalimat untuk disampaikan kepada orang lain, sehingga orang lain dapat memahaminya. Dalam hal ini, dapat terjadinya komunikasi antar penulis dan pembaca dengan baik.

Materi dalam penelitian ini adalah menulis puisi. Menurut Waluyo (2010:1) puisi adalah karya sastra dengan bahasa yang dipadatkan, dipersingkat, dan diberi irama dengan bunyi yang padu dan pemilihan kata-kata kias (imajinatif). Puisi merupakan sebuah karya sastra yang paling unik, karena pada sebuah puisi 
terdapat makna yang disampaikan tidak hanya tersurat, tetapi juga tersirat. Bahkan dapat dipastikan pesan tersirat lebih banyak terkandung dalam sebuah puisi. Kata-kata yang tersusun dalam sebuah puisi tidak sebanyak kata-kata yang terdapat dalam teks fiksi atau cerita. Ketika puisi itu disampaikan juga memiliki ciri khas yang berbeda, karena memiliki rima dan irama tentu dilengkapi penekanan yang berbeda di setiap kata saat dibacakan.

Pembelajaran berpuisi dimaksudkan sebagai pembelajaran yang berkenaan dengan menulis puisi dan mempresentasikannya, dua hal yang tidak terpisahkan karena orientasi dari pembelajaran adalah kompetensi berpuisi. Jadi, konotasinya adalah kemampuan siswa dalam praktik, dengan penekanan pada aspek kinerjanya. Pembelajaran menulis puisi di sekolah merupakan pembelajaran yang paling lengkap karena tidak hanya keterampilan menulis yang dilatih, tetapi melatih juga keterampilan membaca saat siswa membacakan puisi yang telah ditulisnya. Siswa juga akan berlatih intonasi serta ekspresi yang menggambarkan isi puisi tersebut.

Dalam penelitian ini, untuk meningkatkan keterampilan menulis siswa diberikan metode pembelajaran sebagai variabel bebas dalam penelitian ialah metode pembelajaran tebak kata. Digunakan sebagai metode pembelajaran untuk meningkatkan motivasi belajar siswa, dan agar siswa tidak cepat merasa bosan ketika di kelas. Menurut Aqib \& Murtadlo (2012), "metode tebak kata merupakan penyampaian materi ajar dengan menggunakan kata-kata singkat dalam bentuk kartu permainan sehingga anak dapat menerima pesan pembelajaran melalui kartu itu". Metode tebak kata dilaksanakan seperti permainan agar menyenangkan untuk siswa. Siswa dipersilakan mengambil kartu yang telah berisi kata-kata sebgai kunci dari tema puisi yang akan ditulisnya.

Menurut Said \& Budimanjaya (2015: 68), model pembelajaran tebak kata adalah menebak kata yang dimaksud dengan cara menyebutkan kata-kata tertentu sampai kata yang disebutkan tersebut benar. Metode tebak kata melatih siswa untuk terus menemukan banyak kata yang sesuai dengan kata yang terdapat di dalam kartu setelah mendapatkan petunjuk dari teman yang lainnya. Permainan tebak kata ini akan membuat suasana di dalam kelas menjadi 
menyenangkan. Sekaligus dengan tujuan membuat siswa fokus dan semangat belajar menulis puisi.

Dengan demikian, metode tebak kata merupakan metode yang digunakan guru untuk membuat siswa di kelas menjadi aktif. Pembelajaran ini juga dapat melatih dan mengembangkan keterampilan sosial siswa pada saat melakukan kegiatan yang bersifat demokratis seperti diskusi antar siswa. Agar semua siswa dapat menjadi subyek untuk menghindarkan siswa yang diam sama sekali pada saat pembelajaran berlangsung. Sehingga metode ini dapat melatih siswa untuk lebih memperhatikan penjelasan materi yang sedang diberikan serta berani dalam hal berbicara dan mengungkapkan pendapat di depan kelas.

Penelitian berkaitan dengan penerapan metode tebak kata sudah dilakukan oleh Wahyun, dkk. (2014) dengan hasil penelitian, setelah menggunakan metode tebak kata, hasil belajar peserta didik meningkat menjadi lebih baik daripada sebelumnya. Berikutnya pernah juga dilakukan penelitian oleh Iswatin (2011) dengan hasil penelitian yang menunjukkan bahwa metode tebak kata mampu meningkatkan kemampuan membaca peserta didik. Begitupun Hasanah (2014), juga menemukan di dalam penelitiannya bahwa metode tebak kata mampu meningkatkan kemampuan berbicara peserta didik di sekolah dasar yang menjadi sampel penelitiannya. Dari beberapa hasil penelitian ini menunjukkan bahwa metode tebak kata mampu memotivasi siswa dalam meningkatkan keterampilan membaca dan berbicara siswa. Untuk itu, penting dilakukan uji coba penerapan metode tebak kata dalam mempengaruhi keterampilan menulis puisi siswa.

Berdasarkan paparan latar belakang di atas, maka peneliti akan melakukan penelitian tentang metode pembelajaran tebak kata yang berpotensi membuat siswa sebagai pusat pembelajaran termotimativa dalam belajar sehingga mampu mempengaruhi keterampilan menulis puisi. Penelitian ini akan menguji hipotesis "Ada pengaruh yang signifikan metode tebak kata terhadap keterampilan menulis puisi siswa kelas IV SD Negeri Taman Cibodas Kota Tangerang. Dari hasil penelitian ini diharapkan metode tebak kata bisa menjadi alternatif bagi guru dalam meningkatkan kemmapuan menulis puisi di sekolah. 


\section{B. Metode Penelitian}

Penelitian ini dilakukan dengan metode eksperimen semu (quasi eksperiment) dengan desain Nonequivalent Control Group Design. Populasi penelitian adalah kelas IV SDN Taman Cibodas yang berjumlah 62 siswa, sedangkan sampel penelitian terdiri dari dua kelas yaitu kelas IVA dan IVB masing-masing kelas terdiri dari 32 siswa. Teknik pengambilan sampel dengan teknik Sampling Jenuh. Menurut Sugiyono (2016), "Dikatakan Sampling Jenuh adalah teknik penentuan sampel bila semua anggota populasi digunakan sebagai sampel".

Data dalam penelitian ini berupa data kuantitatif. Data kuantitatif berupa hasil tes keterampilan menulis pada materi menulis puisi. Terdiri dari 1 soal keterampilan menulis, untuk melihat pengaruh dari pemberian perlakuan terhadap kelas eksperimen maupun kelas kontrol, maka baik kelas eksperimen maupun kelas kontrol diberikan pretes dan postes. Untuk pretes dan postes digunakan perangkat tes yang berbeda. Data hasil penelitian yang diperoleh selanjutnya dianalisis statistik deskriptif dan inferensial. Pengujian terhadap perbedaan ratarata hasil postest menggunakan teknik statistik uji t-test.

\section{Hasil Penelitian dan Pembahasan}

\section{Hasil Penelitian}

Indikator keterampilan menulis yang berasal dari buku Fahrurozi \& Wicaksono (2016), dapat di lihat dalam tabel 1.

Tabel 1. Distribusi Indikator Keterampilan Menulis

\begin{tabular}{cccc}
\hline Variabel & Kompetensi Dasar & \multicolumn{1}{c}{ Indikator } \\
\hline Keterampilan Menulis & $\begin{array}{c}\text { 8.3 Menulis puisi bebas dengan } \\
\text { pilihan kata yang tepat. }\end{array}$ & 8.3 .1 & $\begin{array}{l}\text { Siswa dapat menulis puisi } \\
\text { berdasarkan majas/gaya } \\
\text { bahasa dengan baik. }\end{array}$ \\
& $8.3 .2 \begin{array}{l}\text { Siswa dapat menulis puisi } \\
\text { berdasarkan diksi yang } \\
\text { baik. }\end{array}$ \\
& $8.3 .3 \begin{array}{l}\text { Siswa dapat membuat puisi } \\
\text { berdasarkan kesatuan } \\
\text { tema dengan baik. }\end{array}$ \\
& $8.3 .4 \begin{array}{l}\text { Siswa dapat membuat puisi } \\
\text { dengan amanat dari } \\
\text { sebuah puisi yang dibuat } \\
\text { dengan baik. }\end{array}$
\end{tabular}

Silampari Bisa: Jurnal Penelitian Pendidikan Bahasa Indonesia, Daerah, dan Asing Vol. 2, No. 1, 2019 
Berdasarkan Tabel 1, setelah soal diuji, semua soal layak digunakan dan telah memenuhi syarat validasi. Selanjutnya tes tersebut digunakan dalam penelitian. Hasil dari data penelitian kemudian diuji normalitas dan uji homogenitas, dan hasilnya dinyatakan memenuhi syarat normalitas dan homogenitas, sehingga dapat dilakukan pengujian hipotesis terhadap tes keterampilan menulis. Secara deskriptif data pretest dan postest untuk keterampilan menulis dapat dilihat pada tabel 2 .

Tabel 2. Hasil Analisis Deskriptif Pretest dan Postest Keterampilan Menulis Kelas Eksperimen dan Kelas Kontrol

\begin{tabular}{|c|c|c|c|c|c|c|c|c|}
\hline $\begin{array}{c}\text { Jenis } \\
\text { Tes }\end{array}$ & Kelas & $\mathbf{N}$ & Min & Max & Mean & Modus & Median & SD \\
\hline Pretes & \multirow{2}{*}{ Eksperimen } & \multirow{2}{*}{32} & 42 & 83 & 63 & 60,8 & 55,5 & 10,10 \\
\hline Postes & & & 42 & 92 & 73 & 74 & 65 & 12,67 \\
\hline Pretes & \multirow{2}{*}{ Kontrol } & \multirow{2}{*}{32} & 33 & 83 & 59 & 62 & 50,5 & 12,90 \\
\hline Postes & & & 33 & 83 & 59 & 57 & 49 & 12,94 \\
\hline
\end{tabular}

Berdasarkan Tabel 2, nilai pretest pada kelompok eksperimen menunjukkan nilai minimum 26 dan maksimum 90 dan untuk nilai postest menunjukkan nilai minimum 52 dan maksimum 98 . Kelompok kontrol nilai pretest menunjukkan nilai minimum 22 dan maksimum 90 dan untuk nilai postest menunjukkan nilai minimum 44 dan maksimum 90. Sehingga disimpulkan nilai pretest maupun postest kelompok eksperimen lebih tinggi dari kelompok kontrol. Hal ini juga dapat dilihat pada tabel 3.

\section{Tabel 3. Ringkasan Nilai Pretest dan Postest}

\begin{tabular}{lcc}
\hline \multicolumn{1}{c}{ Kelas } & Rata-Rata Nilai Pretest & Rata-Rata Nilai Postest \\
\hline Eksperimen & 63 & 73 \\
\hline Kontrol & 59 & 59
\end{tabular}

Tabel 3 di atas, menunjukkan bahwa nilai rata-rata pretest dan postest kelas eksperimen lebih tinggi dari kelas kontrol, kedua kelas tergolong dalam kategori sedang. Berdasarkan hasil analisis uji-t pada variabel keterampilan menulis. Antara kelompok eksperimen dan kelompok kontrol ditunjukkan pada Tabel 4. 
Tabel 4. Uji-t Tes Akhir Keterampilan Menulis Kelas Eksperimen dan Kelas Kontrol

\begin{tabular}{ccc}
\hline Uji-T & Thitung & $\mathbf{T}_{\text {tabel }}(\mathbf{1}-)^{\mathbf{t}}\left(\mathbf{n}_{\mathbf{1}}+\mathbf{n}_{\mathbf{2}} \mathbf{- 2}\right)$ \\
\cline { 2 - 3 } & 4,47 & 2,00 \\
\hline
\end{tabular}

Berdasarkan Tabel 4, menunjukkan $t_{\text {nitung }}=4,47$ lebih besar dari $t_{\text {tabel }}=2,00$ untuk $\mathrm{db}=62$ pada $\alpha=5 \%$, karena $\mathrm{T}_{\text {hitung }}>\mathrm{T}_{\text {tabel }}$ maka $\mathrm{H}_{0}$ ditolak dan hipotesis alternatif $\left(\mathrm{H}_{1}\right)$ diterima. Dapat diartikan bahwa terdapat pengaruh metode tebak kata terhadap keterampilan menulis puisi. Hasil pengujian ini sekaligus membuktikan bahwa terjadi pengaruh pada hasil keterampilan menulis siswa bukan suatu kebetulan, melainkan karena perbedaan perlakuan yang diberikan pada kelas eksperimen dan kelas kontrol. Dengan memberikan perlakuaan menggunakan metode tebak kata dapat berpengaruh positif terhadap keterampilan menulis siswa, serta efisiensi proses belajar mengajar bahasa Indonesia dapat ditingkatkan menggunakan metode tebak kata.

\section{Pembahasan}

Hasil penelitian menunjukkan bahwa terdapat pengaruh metode tebak kata terhadap keterampilan menulis puisi siswa kelas IV SDN Taman Cibodas. Hal ini dibuktikan dengan pengujian hipotesis menggunakan uji perbedaan rata-rata dua sampel bebas yaitu $t_{\text {hitung }}=4,47$ sedangkan $t_{\text {tabel }}=2,00$ dengan demikian $t_{\text {hitung }}>$ $t_{\text {tabel }}(\alpha=0,05)$, maka $H_{0}$ ditolak dan $H_{1}$ diterima. Pembelajaran menulis puisi dengan menerapkan metode tebak kata pada kelas eksperimen dapat mempengaruhi hasil belajar siswa dalam menulis puisi, dikarenakan metode tersebut memiliki kelebihan seperti siswa tidak diam sama sekali di kelas, mendorong siswa untuk meningkatkan inisiatif atau partisipasinya pada saat pembelajaran, dan siswa menjadi aktif dalam proses pembelajaran.

Proses pembelajaran yang demikian, mengakibatkan kegiatan pembelajaran pada kelas eksperimen dan kelas kontrol berpengaruh terhadap keterampilan menulis siswa. Pada kelas eksperimen yang diberikan metode tebak kata memberikan pengaruh lebih baik terhadap keterampilan menulis siswa dibandingkan dengan pembelajaran melalui metode konvensional. Di mana siswa sudah mampu meningkatkan rasa percaya diri jika diperintah untuk maju dan Silampari Bisa: Jurnal Penelitian Pendidikan Bahasa Indonesia, Daerah, dan Asing Vol. 2, No. 1, 2019 
berbicara di depan kelas. Sehingga, siswa di dalam kelas pada saat proses pembelajaran tidak ada yang diam sama sekali karena setiap siswa diberikan kesempatan untuk maju dan berbicara ke depan kelas menyampaikan materi yang sedang diajarkan. Dengan demikian, metode pembelajaran ini dapat meningkatkan motivasi belajar pada siswa, dan pada saat proses pembelajaran berlangsung keterampilan menulis pada siswa dapat meningkat lebih baik.

Penerapan metode tebak kata ini sangat dipengaruhi oleh peran guru dalam memberikan penguatan dan kemampuan dalam membimbing kelompok kecil dalam menemukan kata untuk dituangkan dalam kegiatan menulis puisi. Noermanzah (2018:172) menjelaskan bahwa guru mempunyai peranan penting dalam menciptakan pembelajaran yang variatif, inovatif, efektif, dan menyenangkan sehingga mampu meningkatkan motivasi belajar dan pada akhirnya tujuan pembelajaran akan tercapai. Model pembelajaran tebak kata memberikan peran guru dalam melatih siswa untuk terus menemukan banyak kata yang sesuai dengan kata yang terdapat di dalam kartu setelah mendapatkan petunjuk dari teman yang lainnya (Said \& Budimanjaya, 2015:68). Dengan semakin memberikan penguatan berupa penghargaan dalam bentuk lisan dan kinesik ketika menemukan kata-kata, membuat siswa semakin termotivasi menemukan lebih banyak kata yang akan dituangkan dalam kegiatan menulis puisi.

Hal ini senada dengan penelitian yang dilakukan oleh Wahyun, dkk. (2014) bahwa setelah menggunakan metode tebak kata, hasil belajar peserta didik meningkat menjadi lebih baik daripada sebelumnya. Begitupun dengan penelitian yang dilakukan oleh Iswatin (2011) bahwa metode tebak kata mampu meningkatkan kemampuan membaca peserta didik. Hasanah (2014) juga menemukan di dalam penelitiannya bahwa metode tebak kata mampu meningkatkan kemampuan berbicara peserta didik di sekolah dasar yang menjadi sampel penelitiannya. Artinya, metode tebak kata dapat memotivasi peserta didik untuk selalu semangat dalam belajar. Hal ini dikarenakan, kondisi diri yang stabil selama belajar, akan memberi dampak yang baik terhadap peserta didik (Maisarah, dkk., 2018). 


\section{Simpulan}

Hasil penelitian menunjukkan bahwa terdapat pengaruh metode tebak kata terhadap keterampilan menulis puisi siswa kelas IV SDN Taman Cibodas. Hal ini dibuktikan dengan pengujian hipotesis menggunakan uji perbedaan rata-rata dua sampel bebas yaitu $t_{\text {hitung }}=4,47$ sedangkan $t_{\text {tabel }}=2,00$ dengan demikian $t_{\text {hitung }}>$ $t_{\text {tabel }}(\alpha=0,05)$, maka $\mathrm{H}_{0}$ ditolak dan $\mathrm{H}_{1}$ diterima. Berdasarkan hasil belajar menulis puisi yang diperoleh siswa, dapat disimpulkan bahwa terdapat pengaruh keterampilan menulis pada siswa yang belajar menggunakan model pembelajaran tebak kata dibandingkan dengan metode konvensional.

Berdasarkan hasil penelitian yang telah dilakukan, menunjukkan bahwa dengan menggunakan metode pembelajaran tebak kata terdapat pengaruh terhadap keterampilan menulis pada siswa kelas V. Pada saat penerapan pembelajaran di kelas dengan menggunakan model tersebut dapat membuat siswa lebih aktif dan termotivasi dalam belajar, karena pembelajaran yang dilakukan lebih banyak melibatkan siswa di dalamnya, sehingga siswa lebih mudah paham terhadap materi pelajaran yang diberikan, dan tidak ada siswa yang diam sama sekali pada saat proses pembelajaran berlangsung. Dapat dikatakan pembelajaran di kelas berjalan dengan lancar dan mendapatkan hasil yang baik, sehingga metode pembelajaran tebak kata dapat diterapkan di kelas oleh guru untuk memberikan variasi pada proses pembelajaran agar pembelajaran tidak cepat terasa bosan khususnya pada materi menulis puisi.

\section{Daftar Pustaka}

Aqib, Z. \& Murtadlo, A. (2012). Kumpulan Metode Pembelajaran Kreatif \& Inovatif. Bandung: Satu Nusa.

Fadhillah, D., dkk. (2019). Pembelajaran Bahasa Indonesia Kelas Tinggi. Yogyakarta: Samudra Biru.

Fahrurrozi \& Wicaksono, A. (2016). Sekilas tentang Bahasa Indonesia. Yogyakarta: Garudhawaca. 
Hasanah, S. N. (2014). Peningkatan Keterampilan Berbicara melalui Metode Tebak Kata dalam Pembelajaran Bahasa Indonesia pada Siswa Kelas II SD Negeri 01 Jetis Kecamatan Jaten Kabupaten Karanganyar Tahun Ajaran 2013/2014. (Doctoral Dissertation, Universitas Muhammadiyah Surakarta).

Iswatin, E. (2011). Peningkatan Keterampilan Berbicara melalui Penggunaan Metode Petekabar (Permainan Tebak Kata dan Gambar) pada Siswa Kelas I SDN Watudakon II Kecamatan Kesamben Jombang (Doctoral Dissertation, University Of Muhammadiyah Malang).

Maisarah, I., Zaim, M., Syarif, H., \& Bentri, A. (2018). Designing Affective Instrument Based on Scientific Approach for English Language Learning. SHS Web Conference GC-TALE. No. 42. https://doi.org/10.1051/shsconf/ 20184200068.

Noermanzah, N., Abid, S., \& Aprika, E. (2018). Pengaruh Teknik Send a Problem terhadap Kemampuan Menulis Daftar Pustaka Siswa Kelas XI SMA Negeri 4 Lubuklinggau. Jurnal Kajian Bahasa, Sastra dan Pengajaran (KIBASP), 1(2), 171-181. doi:10.31539/kibasp.v1i2.273

Said, A. \& Budimanjaya, A. (2015). 95 Strategi Mengajar Multiple Intelligences. Jakarta: Prenadamedia group.

Sugiyono. (2016). Metode Penelitian Kuantitatif, Kualitatif, dan R\&D. Bandung: Alfabeta.

Tarigan, H. G. (2008). Membaca sebagai Suatu Keterampilan Berbahasa. Bandung: Angkasa.

Wahyun, T., Marli, S., \& Sabri, T. (2014). Peningkatan Motivasi Belajar Siswa dengan Menggunakan Model Kooperatif Teknik Tebak Kata di Sekolah Dasar. Jurnal Pendidikan dan Pembelajaran, 3(11).

Waluyo, H.J. (2010). Pengkajian dan Apresiasi Puisi. Salatiga: Widyasari. 